УДК 341.45

DOI https://doi.org/10.32837/apdp.v0i90.3212

I. М. Леган

\title{
ОСНОВНІ НАПРЯМИ Й ФОРМИ МІЖНАРОДНОГО СПІВРОБІТНИЦТВА ЩОДО ЗАПОБІГАННЯ ТА ПРОТИДІЇ ТРАНСНАЦІОНАЛЬНІЙ ЗЛОЧИННОСТІ
}

Постановка проблеми. В останні десятиліття чітко проявляється тенденція до розширення і поглиблення міжнародного співробітництва у правоохоронній сфері щодо запобігання та протидії транснаціональній злочинності. Це обумовлено швидким розвитком інтеграційних процесів у світі, розширенням політичних, економічних, культурних і гуманітарних зв'язків, вдосконаленням засобів транспорту та зв'язку, спрощенням порядку перетину кордонів між країнами, прикордонних і митних формальностей, затвердженням у міжнародних відносинах пріоритету загальнолюдських цінностей, ідей справедливості і солідарності.

Аналіз останніх досліджень і публікацій. Проблемі, що пов'язані з особливостями міжнародного співробітництва у питаннях із протидією та запобіганням транснаціональній злочинності, присвячені наукові доробки таких вчених, як Свистуленко М.П., Юртаєва К.В., Моісеєв О.І. та інші. Попри підвищену зацікавленість вчених до актуальних питань даної проблематики, окремі аспекти щодо форм та проявів міжнародного співробітництва щодо запобігання та протидії транснаціональній злочинності досліджені в наукових публікаціях недостатньо. Саме цей фактор спровокував написання даної наукової роботи.

Метою статті є визначення основних напрямів та форм міжнародного співробітництва щодо запобігання та протидії транснаціональній злочинності у світі.

Виклад основного матеріалу. Співробітництво держав у галузі боротьби зі злочинністю та забезпечення громадської безпеки має об'єктивну основу - їх тісний взаємозв' язок і взаємозалежність, яким передують якісна зміна самої злочинності, в тому числі її інтернаціоналізація, тобто зростання в ній питомої ваги міжнародного елементу (наприклад, вчинення злочину на території двох і більше держав, приховування та збут викраденого або відмивання доходів, одержаних злочинним шляхом за кордоном, спроби злочинців сховатися від правосуддя за кордоном і т.д.).

Проблема злочинності з кожним роком все більше набуває глобального та міжнародного характеру. Транснаціональна організована злочинність - це проблема, яка завдає величезної шкоди економіці і підриває безпеку держав. Торгівля людьми, контрафакція, незаконний оборот наркотиків, торгівля зброєю, незаконне ввезення мігрантів та екологічні злочини приносять злочинцям прибуток в розмірі 870 мільярдів доларів США в рік, що більш ніж у шість разів перевищує обсяг офіційної допомоги на Цілі сталого розвитку.

Сьогодні Управління ООН із боротьби з наркотиками і транснаціональною організованою злочинністю наголошує на тому, що «транснаціональна організована злочинність стосується кожного регіону і кожної країни в усьому світі, боротьба 3 цією транснаціональною загрозою є одним з найважливіших глобальних завдань міжнародної спільноти» [5].

(C) I. М. Леган, 2021 
Транснаціональна організована злочинність призводить не тільки до величезних фінансових втрат, а й до втрати людських життів. Мільйони людей гинуть внаслідок вживання наркотиків, застосування насильства, вогнепальної зброї, в зв’язку з контрабандою та торгівлею людьми.

Експерти ООН відзначають, що діяльність злочинних груп можуть призвести до дестабілізації окремих країн і цілих регіонів. За даними ООН, найбільшу вигоду злочинці отримують від незаконного обігу наркотиків - близько 320 мільярдів доларів США в рік, 250 мільярдів доларів в рік кримінальні угруповання отримують в результаті контрафакції, тобто продажу підробних товарів. Торгівля людьми приносить світовим злочинцям близько 32 мільярдів доларів США щорічно, а незаконне перевезення мігрантів - до 7 мільярдів доларів на рік.

Чималий прибуток учасники злочинних мереж отримують від незаконної експлуатації навколишнього середовища. Незаконна торгівля деревиною тільки в регіоні Південно-Східної Азії генерує доходи в розмірі 3,5 мільярда доларів на рік, а продаж слонової кістки, рогів носорога і частин тигра приносить злочинним угрупованням близько 75 мільйонів доларів США щорічно.

Для Європейського Союзу проблема транснаціональної злочинності також становить суттєву загрозу безпеці. За даними Європолу, головним джерелом доходу для близько $40 \%$ європейських транснаціональних злочинних угруповань $є$ незаконний обіг наркотиків, а спалах епідемії, пов'язаної з вірусом COVID-19, тільки розширив коло їхньої діяльності [6].

Європол фіксує, що боротьба з великими злочинними угрупуваннями ускладнюється їхньою транснаціональною структурою, адже 70\% злочинних мереж діють, як мінімум, у трьох різних країнах. Крім того, протягом вимушеної ізоляції зросла частка випадків шахрайства в мережі Інтернет. Короновірусна криза посилена вплив таких явищ, як транскордонна корупція, криміналізація бізнесу і відмивання величезних сум коштів, отриманих злочинним шляхом.

Єврокомісар із питань внутрішніх справ Європейського Союзу відмічає, що «за один рік злочинці заробили в ЄС майже 140 млрд. євро «брудних грошей», а це 1\% ВВП Євросоюзу і більше, ніж весь ВВП деяких країн-членів СС» [6]. Тому цілком логічним у даному напрямі є посилення співпраці правоохоронних організацій та судових систем.

Основним міжнародним документом у напрямку боротьби з організованою злочинністю є Конвенція Організації Об’єднаних Націй проти транснаціональної організованої злочинності.

У даному напрямі ООН допомагає країнам застосовувати положення Конвенції з метою виділення у внутрішньому законодавстві відповідних складів злочинів для боротьби з проблемою транснаціональної злочинності, створення нових механізмів взаємної правової допомоги, спрощення видачі, налагодження співпраці правоохоронних органів, надання технічної допомоги та організації підготовки кадрів.

У сучасних умовах глобалізації розширюється й спектр організованої злочинної діяльності. На зміну традиційним ієрархічним формам організації злочинної діяльності приходять більш вільні мережеві структури, які взаємодіють між собою. Наприклад, організовані злочинні групи, які здійснюють незаконний обіг 
наркотиків, як правило, займаються контрабандою та розповсюдженням інших нелегальних товарів. Зв'язок між незаконним обігом наркотиків та іншими існуючими формами транснаціональної організованої злочинності вимагає застосування комплексного підходу її запобігання. Підписання 2000 року Конвенції Організації Об’єднаних Націй проти транснаціональної організованої злочинності стало важливим кроком в боротьбі з цією загрозою.

Конвенція Організації Об’єднаних Націй [4] проти транснаціональної організованої злочинності, яка вступила в силу у вересні 2003 року, є головним міжнародним документом в боротьбі з організованою злочинністю. Конвенція зобов'язує держави вживати необхідні заходи, включаючи створення нових механізмів взаємної правової допомоги між державами, видачу, налагодження співпраці міжнародних правоохоронних органів, надання технічної допомоги та підготовку необхідних кадрів.

Крім того, згідно з Конвенцією Організації Об’єднаних Націй державам-членам можливе надання допомоги в таких основних напрямах [9], як:

1) моніторинг виконання Конвенції;

2) розробка та заохочення застосування найбільш ефективних методів боротьби з організованою злочинністю в усьому світі;

3) удосконалення процесу обміну інформацією, співпраці судових органів і взаємну правову допомогу між співробітниками правоохоронних органів;

4) виявлення найбільш ефективних методів збору інформації про організовану злочинність в регіональному та глобальному масштабах і забезпечення вільного доступу цієї інформації для цілей розробки політики та здійснення проектів технічної допомоги.

Різні види та прояви злочинності в більш чи менш гострій формі проявляються у всіх країнах світу, будучи серйозною реальною або потенційною перешкодою на шляху їх соціально-економічного, політичного та культурного розвитку. Це зумовлює зацікавленість всіх членів світової спільноти в спільному пошуку найбільш дієвих шляхів і засобів вирішення даної проблеми. Адже, як стверджують науковці, сучасна злочинність, особливо в її найбільш небезпечних організованих формах і у вигляді міжнародного тероризму, не знає меж та кордонів.

Крім того, постійно розширюється перелік злочинних діянь, що представляють міжнародну небезпеку (наприклад, незаконний транскордонний обіг наркотиків, культурних цінностей, зброї, торгівля людьми, дитяча порнографія тощо). Протидія та запобігання таким злочинам може бути по-справжньому ефективна тільки за умови узгодженості дій більшості держав, а також раціонального поєднання внутрішньодержавних та міжнародних зусиль.

Доцільно виділити такі основні напрямки міждержавного співробітництва в боротьбі із транснаціональною злочинністю:

1. Обмін інформацією, в тому числі оперативною, криміналістичною, правовою.

2. Виконання запитів про проведення оперативно-розшукових заходів.

3. Надання правової допомоги у кримінальних справах.

4. Екстрадиція осіб для притягнення їх до кримінальної відповідальності або для виконання вироку. 
5. Укладення та реалізація міжнародних договорів у протидії злочинам, що загрожують міжнародній небезпеці.

6. Розробка міжнародних норм обов'язкового або рекомендаційного характеру у сфері охорони правопорядку та кримінального правосуддя.

7. Визнання та виконання рішень компетентних органів іноземних держав у кримінальних та адміністративних справах.

8. Проведення спільних наукових досліджень, пов'язаних із проблемами протидії та запобігання злочинності, обмін досвідом щодо їх вирішення.

9. Надання матеріальної, технічної та експертної допомоги (підготовка та підвищення кваліфікації кадрів, надання експертних послуг тощо).

Співпраця правоохоронних органів має здійснюватися в режимі міжнародної законності, тобто при точному і неухильному дотриманні міжнародно-правових норм, а в першу чергу - загальновизнаних норм міжнародного права.

Здійснюючи взаємодію в правоохоронній сфері, держави використовують дві основні правові форми:

1. Договірно-правова або конвенційна - висновок і реалізація двосторонніх або багатосторонніх договорів, в яких регулюються відносини в даній сфері, з правоохоронними органами іноземних держав.

2. Інституційна - співпраця в рамках міжнародних організацій, як загального, так і регіонального характеру: ООН, Інтерпол, СНД, Рада Європи, ОБСЄ, Організація Чорноморського економічного співробітництва, Шанхайська організація співробітництва та ін.

Висновки і пропозиції. Органи внутрішніх справ України беруть активну участь у виконанні зобов'язань за всіма основними напрямками міждержавного співробітництва щодо запобігання та протидії транснаціональній злочинності та забезпечення громадської безпеки, і їхня діяльність у даному напрямку здійснюється в тісній взаємодії з іншими міжнародними правоохоронними органами.

\section{Jimepamypa}

1. Legan I.M., Bondarenko K.S. Features of the free legal aid system in Ukraine and the European Union countries. Держава та регіони. Серія: Право. 2020. № 3(69). С. 148-151.

2. Леган I.М., Антонюк А.Б. Перспективи розвитку законодавчого регулювання системи безоплатної правової допомоги в Україні в контексті європейської інтеграції. Прикарпатський юридичний вісник. Випуск 3(32). 2020. С. 3-6.

3. Невмержицький С.М. Сутність етнічної організованої злочинності в Україні. Актуальні проблеми вітчизняної юриспруденції. № 1. 2019. С. 191-194.

4. Організована злочинність в Україні та країнах Європи : [посіб.] / за заг. ред. проф. О.М. Джужі. Київ, 2007. 248 с.

5. Офіційна сторінка Управління ООН по боротьбі з наркотиками і транснаціональною організованою злочинністю. URL : https://www.unodc.org/unodc/ru/strategy/full-strategy.html.

6. Офіційний сайт Європолу. URL : https://www.europol.europa.eu/.

7. Перепьолкін C.М. Міжнародне співробітництво у сфері правоохоронної діяльності : навч. посіб. Дніпро : Дніпроп. держ. ун-т внутр. справ, 2018. 112 с.

8. Трунцевский Ю.В. Понятие транснационального преступления. Международное уголовное пра во и международная юстищия. 2014. № 3. С. 9-12.

9. Яценко В.А. Транснациональная организованная преступность: криминологическая характеристика и предупреждение : дис. ... канд. юрид. наук. Ростов-на-Дону : РГУ, 2003. 194 с. 


\section{Анотація}

Леган I. М. Основні напрями й форми міжнародного співробітництва щодо запобігання та протидії транснаціональній злочинності. - Стаття.

У статті розглядаються правові основи та основні напрямки діяльності правоохоронних організацій у сучасних умовах. Визначено, що у світі створено глобальну поліцейську інформаційну мережу, iii цілі та завдання реалізуються переважно шляхом інформаційного забезпечення міжнародного розшуку та ведення міжнародних криміналістичних обліків, а також інформаційного забезпечення боротьби з окремими видами злочинів. Однак сучасні тенденції злочинності, їх міжнародна складова частина вимагають не тільки інформації, але й спільних дій із недопущення й розкриття злочинів. Це зумовило формування регіональних організацій по співпраці між сучасними правоохоронними органами. У статті доведено, що сучасні глобалізаційні процеси у світі та розвиток інформаційного суспільства, новітні засоби комунікації та цифрові технології актуалізують питання транснаціональної злочинності та виводять її на зовсім інший рівень. У статті охарактеризовано, що під впливом різних інститутів громадянського суспільства, а також наростаючої терористичної загрози, збільшення обсягів кримінальної торгівлі зброєю, наркотиками і легалізації (відмивання) коштів, отриманих злочинним шляхом, які останнім часом набули транснаціонального характеру, державні органи змушені з усією відповідальністю поставитися до забезпечення громадської і державної безпеки через підвищення професіоналізму співробітників правоохоронних органів. Виділено основні характеристики сучасної організованої злочинності, серед яких: стійкий та довготривалий характер, жага до отримання надприбутків, попереднє планування своєї діяльності та визначення ролі кожного члена у групі, чітка диференціація на керівників різного рівня та виконавців, організація спільних грошових страхових запасів. У статті доведено, що співпраця в напрямку протидії та запобігання транснаціональній злочинності ведеться відносно певних категорій злочинів. Вказано, що, крім того, здійснюється обмін досвідом, нормативно-правовими актами та методичними посібниками, організовуються спільні семінари, ознайомчі візити та консультації. У статті проаналізовано, що сторони у ході міжнародного співробітництва можуть обмінюватися стратегічною та технічною інформацією, яка становить взаємний інтерес, а також аналітичними матеріалами з різних аспектів боротьби з організованою транснаціональною злочинністю, в тому числі з міжнародним тероризмом.

Ключові слова: правоохоронні організації, транскордонні злочини, правова допомога, організовані злочинні групи, Конвенція ООН.

\section{Summary}

Legan I. M. The main directions and forms of international cooperation in preventing and combating transnational crime. - Article.

The article considers the legal basis and main activities of law enforcement agencies in modern conditions. It is determined that a global police information network has been created in the world, its goals and objectives are realized mainly through information support of international search and international forensic records, as well as information support of the fight against certain types of crimes. However, current trends in crime, their international component require not only information but also joint action to prevent and detect crimes. This led to the formation of regional organizations for cooperation between modern law enforcement agencies. The article proves that modern globalization processes in the world and the development of the information society, the latest means of communication and digital technologies raise the issue of transnational crime and take it to a completely different level. The article describes that under the influence of various civil society institutions, as well as the growing terrorist threat, increased criminal trade in weapons, drugs and money laundering, which has recently become transnational in nature, public authorities are forced to take full responsibility. to ensure public and state security by improving the professionalism of law enforcement officers. The main characteristics of modern organized crime are highlighted, including: sustainable and long-term nature, thirst for profit, preliminary planning of their activities and determining the role of each member in the group, clear differentiation into managers and executors, organization of joint monetary insurance reserves. The article proves that cooperation in combating and preventing transnational crime is conducted in relation to certain categories of crimes. It is described that in addition, there is an exchange of experience, regulations and manuals, joint seminars, study visits and consultations. The article analyzes that the parties in the course of international cooperation may exchange strategic and technical information of mutual interest, as well as analytical materials on various aspects of the fight against organized transnational crime, including international terrorism.

Key words: law enforcement organizations, cross-border crimes, legal aid, organized crime groups, UN Convention. 